\title{
EDUSAINS
}

Jurnal berisi artikel dan hasil penelitian dalam pendidikan sains

Diterbitkan oleh Center for Science Education (CSE) berkedudukan di Jurusan

Pendidikan IPA Fakultas Ilmu Tarbiyah dan Keguruan, UIN Syarif Hidayatullah

Jakarta

\section{Penyunting Ahli}

Salamah Agung (Pendidikan IPA, UIN Syarif Hidayatulah)

Ely Djulia (Pendidikan Biologi, UNIMED)

Ida Faridach (Pendidikan Kimia, UIN Sunan Gunung Djati)

Ismet (Pendidikan Fisika, Universitas Sriwijaya)

Dwi Nanto (Pendidikan IPA, UIN Syarif Hidayatulah)

Zulfiani (Pendidikan IPA, UIN Syarif Hidayatulah)

Suroso (Pendidikan IPA, Universitas Sultan Ageng Tirtayasa)

Anna Fitri Hindriana (Pendidikan IPA, Universitas Kuningan)

Fahyudin (Universitas Haluoleo)

Riskan Qadar (Universitas Mulawarman)

Munas Priyanto (Pendidikan IPA, UIN Syarif Hidayatulah)

Sujiyo Miranto (Pendidikan IPA, UIN Syarif Hidayatulah)

\section{Pimpinan Redaksi}

Yanti Herlanti

\section{Redaktur Pelaksana/Editor}

Meiry Fadilah Noor

Nanda Saridewi

Fathiah Alatas

\section{Desain Grafis}

Yazid Hady

Qumillaila

\section{Sekretariat}

Sulamah Susilawati

Masyudi

\section{CENTER FOR SCIENCE EDUCATION}

Jurusan Pendidikan IPA

Gedung FITK Lt. 6

Jl. Ir. H. Djuanda No 95 Ciputat 15412

Telp/Fax: (021) 8432228

Email:

edusains-fitk@uinjkt.ac.id

\section{Website:}

http://journal.uinjkt.ac.id/index.php/edusains 


\section{PENGANTAR}

Jurnal Edusains mulai volume 5 melakukan perubahan tampilan. Hal ini sesuai rekomendasi dari Peraturan Direktur Jenderal Pendidikan Tinggi Kementerian Pendidikan Nasional Republik Indonesia NOMOR 49/DIKTI/Kep/2011 tentang Pedoman Akreditasi Terbitan Berkala Ilmiah butir D.1 dijelaskan UNESCO merekomendasikan agar terbitan berkala ilmiah diterbitkan dengan kertas berukuran A4 (210 x $297 \mathrm{~mm})$.

Pada volume 8 (delapan) nomor 2 (dua) terdiri dari 13 artikel. Semua artikel berupa hasil kajian penelitian. Metode penelitian yang digunakan oleh para penulis meliputi penelitian deskriptif, eksperimen, pengembangan, dan tindakan kelas.

Porposi artikel yang berasal dari luar UIN Syarif Hidayatullah masih sedikit. Hanya $70 \%$ artikel yang ditulis oleh penulis di luar institusi UIN Syarif Hidayatullah Jakarta.

Edisi jurnal kali ini masih jauh dari kata sempurna walaupun telah mengalami penyuntingan berkali-kali. Kami berharap semoga artikel dalam jurnal ini bermanfaat.

Jakarta 22 November 2016

Dewan Penyunting 


\section{DAFTAR ISI}

Rosita Putri Rahmi Haerani \& Riandi

1 Penggunaan Media Pembelajaran Video Game IPA untuk Meningkatkan

Penguasaan Konsep Siswa

\section{Surya Warni Ridyah \& Siti Sriyati}

2 Pembelajaran IPA Terpadu Tipe Connected dengan Model Experiential

Learning untuk Meningkatkan Keterampilan Proses Sains Siswa SMP

\section{Yesi Nofla Meri \& Ana Ratna Wulan}

Penerapan Model Pembelajaran Brain Based Learning Menggunakan

3 Pembelajaran IPA Terpadu Tipe Webbed dan Connected pada Materi Pemanasan Global untuk Meningkatkan Penguasaan Konsep dan KPS

\section{Mirnawati \& Dadi Rusdiana}

Implementasi Model Pembelajaran Discovery untuk Mengembangkan

4 Keterampilan Dasar Bekerja Ilmiah pada Materi Indera Penglihatan dan Alat Optik

\section{Nurul Ashri \& Lilik Hasanah}

5 Uji Keterpahaman dan Kelayakan Bahan Ajar IPA Terpadu

\section{Irma Suryani, Yuke Mardiati, \& Yanti Herlanti}

6 Pengaruh Penggunaan Lembar Kerja Siswa (LKS) Berbasis Kontekstual terhadap Hasil Belajar Siswa pada Konsep Sistem Gerak Manusia

\section{Al Hafit Nur, Wahyu Sopandi, \& Iqbal Mustapha}

Analisis Pengembangan Karakter, Keterampilan Proses Sains, dan

7 Penguasaan Konsep Siswa pada Topik Koloid melalui Pembelajaran Inkuiri Terbimbing

\section{Gia Juniar Nur Wahidah \& Sjaeful Anwar}

8 Pengembangan Bahan Ajar IPA SMP pada Tema Energi dalam Tubuh Menggunakan Metode 4S TMD

\section{Rahmawati, Sugiarti, \& Yanti Herlanti}

9 Penerapan Sikap Kepedulian Lingkungan dalam Model Sains Teknologi Masyarakat dalam Konsep Ekologi dan Pencemaran Lingkungan

\section{Melia Noprianda, Meiry Fadilah Noor, \& Zulfianih}

10 Keterampilan Berpikir Kritis Siswa Model Pembelajaran Problem Based Learning dan Sains Teknologi Masyarakat pada Konsep Virus

Rizkia Suciati \& Yuni Astuti

11 Analisis Rencana Pelaksanaan Pembelajaran (RPP) Mahasiswa Calon Guru Biologi

\section{Yenni Kurniawati \& Yuni Fatisa}

12 Evaluasi Program Pemodelan dan Simulasi Laboratorium Kimia pada Mahasiswa Calon Guru 
Dendy Siti Kamilah, Iwan Permana Suwarna

13 Pengembangan Three-Tier Test Digital untuk Mengidentifikasi

Miskonsepsi pada Konsep Fluida Statis 